This Accepted Author Manuscript is copyrighted and published by Elsevier. It is posted here by agreement between Elsevier and University of Brasilia. Changes resulting from the publishing process - such as editing, corrections, structural formatting, and other quality control mechanisms - may not be reflected in this version of the text. The definitive version of the text was subsequently published in [Theriogenology, Volume 77, Issue 2, January 2012, Pages 260-267, doi:10.1016/j.theriogenology.2011.07.038].You may download, copy and otherwise use the AAM for non-commercial purposes provided that your license is limited by the following restrictions:

(1) You may use this AAM for non-commercial purposes only under the terms of the CC-BY-NC-ND license.

(2) The integrity of the work and identification of the author, copyright owner, and publisher must be preserved in any copy.

(3) You must attribute this AAM in the following format: [agreed attribution language, including link to CC BY-NC-ND license + Digital Object Identifier link to the published journal article on Elsevier's ScienceDirect $₫$ platform].

Este Manuscrito do Autor Aceito para Publicação (AAM) é protegido por direitos autorais e publicado pela Elsevier. Ele esta disponível neste Repositório, por acordo entre a Elsevier e a Universidade de Brasília. As alterações decorrentes do processo de publicação - como a edição, correção, formatação estrutural, e outros mecanismos de controle de qualidade - não estão refletidas nesta versão do texto. A versão definitiva do texto foi posteriormente publicado em [Theriogenology, Volume 77, Número 2, Janeiro 2012, Pages 260-267, doi:10.1016/j.theriogenology.2011.07.038]. Você pode baixar, copiar e utilizar de outra forma o AAM para fins não comerciais, desde que sua licença seja limitada pelas seguintes restrições:

(1) Você pode usar este AAM para fins não comerciais apenas sob os termos da licença CC- BY- NC-ND.

(2) A integridade do trabalho e identificação do autor, detentor dos direitos autorais e editor deve ser preservado em qualquer cópia.

(3) Tem de atribuir este AAM no seguinte formato: [acordo na linguagem atribuída, incluindo o link para CC BY-NC-ND licença Digital + DOI do artigo publicado na revista Elsevier ScienceDirect ${ }^{\circledR}$ da plataforma]. 


\title{
Ultrastructural features of agouti (Dasyprocta aguti) preantral follicles cryopreserved using dimethyl sulfoxide, ethylene glycol and propanediol
}

\author{
Livia Schell Wanderleya ${ }^{1}$ \\ Hiédely Kenia Machado Luza \\ Luciana Rocha Faustino \\ Isadora Machado Teixeira Lima \\ Cláudio Afonso Pinho Lopes \\ Alexandre Rodrigues Silva \\ Sônia Nair Báo \\ Claudio Cabral Campello \\ Ana Paula Ribeiro Rodrigues \\ José Ricardo de Figueiredo
}

\begin{abstract}
The objective was to develop an efficient protocol for cryopreservation of agouti (Dasyprocta aguti) ovarian tissue. Agouti ovarian fragments were placed, for $10 \mathrm{~min}$, in a solution containing MEM and fetal bovine serum plus $1.5 \mathrm{M}$ dimethyl sulfoxide (DMSO), ethylene glycol (EG) or propanediol (PROH); some of those fragments were subsequently cryopreserved in a programmable freezer. After exposure and/or thawing, all samples were fixed in Carnoy prior to histological analysis. To evaluate ultrastructure, follicles from the control and all cryopreserved treatments were fixed in Karnovsky and processed for transmission electron microscopy. After exposure and freezing, there was a significant decrease in the percentage of morphologically normal preantral follicles in all treatments when compared to the control $(92.67 \pm 2.79$, mean \pm SD). However, there were no significant difference when the exposure and freezing procedures were compared using the same cryoprotectant. Moreover, there was no significant difference among cryoprotectants at the time of exposure (DMSO: $64.7 \pm 3.8$; EG: $70.7 \pm 11.2$, PROH: $63.3 \pm$ 8.5) or after freezing (DMSO: $60.6 \pm 3.6$, EG: $64.0 \pm 11.9$; PROH: $62.0 \pm 6.9$ ). However, only follicles frozen with $\mathrm{PROH}$ had normal ultrastructure. In conclusion, preantral follicles enclosed in agouti ovarian tissue were successfully cryopreserved using $1.5 \mathrm{M} \mathrm{PROH}$, with satisfactory maintenance of follicle morphology and ultrastructure.
\end{abstract}

Keywords: Preantral follicles; Freezing; Agouti; Ultrastructure; Follicle morphology

\section{Introduction}

Cryopreservation of ovarian tissue has been widely studied to preserve the large contingent of female gametes present in preantral follicles (PAF), which are considered the ovarian follicle reserve. Various cryoprotectant agents (CPAs), e.g., ethylene glycol, dimethyl sulfoxide and propanediol, have been successfully used for PAF cryopreservation in various

\footnotetext{
${ }^{1}$ Corresponding author. Tel: 55-85-3101-9860; fax: 55-85-3101-9840. E-mail address: livia_sch@yahoo.com.br (L.S. Wanderley).
} 
animals, including sheep [1], goats [2,3], primates [4], rodents [5], and humans [6]. Satisfactory results have been reported, especially when a $1.5 \mathrm{M}$ concentration was used in slow-freezing protocols. An important application of ovarian tissue cryopreservation is preservation of female gametes of endangered species, which can be stored in germplasm banks and, thereafter, be cultured in vitro or transplanted to support ART that require mature oocytes.

Nevertheless, due to the low availability of endangered species for use in scientific research, it is necessary to use experimental models, usually domestic animals or animals that are not under the threat of extinction, that are phylogenetically close to the species of interest [7]. Hamelett and Rasweiler [8] highlighted the importance of finding new animal species with the potential to be used as experimental models, to support the development of vital research to endangered animals and even humans. In this context, we highlight agouti (Dasyprocta aguti) because it has characteristics that are important for an ideal experimental model for wild rodents threatened with extinction, including small size, low maintenance costs, and a short gestation [9]. Furthermore, agoutis also represent an alternative protein source with the potential for economic exploitation [10]. Therefore, obtaining information regarding reproduction of this species will also provide information for their rational production and consequent preservation [11]. In this regard, several studies have been performed involving the reproductive characteristics of agoutis, such as placentation [10], morphology of the ovaries [12] and oviducts [13], semen collection, and semen cryopreservation $[14,15]$.

The development of a cryopreservation protocol of agouti ovarian tissue might be of great importance for this technique to be applied to the preservation of this species and also to other endangered rodents. However, there are apparently no available studies on the cryopreservation of agouti ovarian tissue. Thus, the objective of this study was to assess the feasibility of the cryopreservation of preantral follicles enclosed in the ovarian tissue of these animals by testing various CPAs, including dimethyl sulfoxide (DMSO), propanediol (PROH) and ethylene glycol (EG), and assessing follicle morphology and ultrastructure.

\section{Materials and methods}

\subsection{Animals}

The Animal Use Ethics Committee of the State University of Ceará approved this study. The agoutis (Dasyprocta aguti) used during the experiment belonged to the Centre of Multiplication of Wild Animals from Rural Federal University of Semi-Arid, located in the northeast of Brazil 
(Mossoró, RN, Brazil; $5^{\circ} 10=\mathrm{S}, 37^{\circ} 10=\mathrm{W}$ ). The climate there is typically semi-arid with a mean annual temperature of $27^{\circ} \mathrm{C}$. The animals were fed seed and fruits, with ad libitum access to water.

\subsection{Source and preparation of ovaries}

Pairs of ovaries $(n=5)$ were collected immediately after euthanasia, rinsed once with $70 \%$ ethanol for $10 \mathrm{~s}$ and twice in HEPES-buffered Minimum Essential Medium (H-MEM, osmolarity 280 $\mathrm{mOsmol} / \mathrm{L}, \mathrm{pH}$ 7.2; Sigma, St. Louis, MO, USA) and transported to the laboratory in $50-\mathrm{mL}$ tubes (Corning Glass Works, Corning, NY, USA) containing $15 \mathrm{~mL}$ of $\mathrm{H}-\mathrm{MEM}$ at $4{ }^{\circ} \mathrm{C}$ within $1 \mathrm{~h}$ after collection.

\subsection{Exposure and freeze thaw procedures}

In the laboratory, ovaries were divided into four equal portions (approximately $4 \quad 4 \quad 1 \mathrm{~mm}$ ); two pieces from each ovarian pair were randomly selected to be the control and were immediately fixed for histological and ultrastructural analysis. The remaining pieces were individually placed in 2-mL maxi-straws (MINITUB do Brasil Ltda., Porto Alegre, RS, Brazil) containing $1.8 \mathrm{~mL}$ of HMEM (HMEM 10\% fetal bovine serum; Laborclin, Pinhais, PR, Brazil) to which either $1.5 \mathrm{M}$ dimethyl sulfoxide (DMSO), ethylene glycol (EG) or propanediol (PROH) was added. Exposure of ovarian fragments to the described solutions was performed at $20{ }^{\circ} \mathrm{C}$ for $10 \mathrm{~min}$. After exposure, three ovarian fragments were subjected to cryoprotectant removal from the tissue at room temperature by three washes ( 5 min each) in MEM with $10 \%$ FBS and decreasing sucrose concentrations (0.5, 0.25 , and $0 \mathrm{M})$. The remaining fragments were cryopreserved using a programmable freezer (Freeze Control, CryoLogic Pty Ltd., Waverley, Australia) as previously described by Faustino et al [16]. Briefly, maxi-straws were cooled at a rate of $2{ }^{\circ} \mathrm{C} / \mathrm{min}$ from 20 to $7^{\circ} \mathrm{C}$, and then ice-induction (seeding) was manually performed by touching the maxistraws with forceps that had been precooled in liquid nitrogen. After seeding, the maxi-straws were held at this temperature $\left(7^{\circ} \mathrm{C}\right)$ for $10 \mathrm{~min}$, cooled at a rate of $0.3^{\circ} \mathrm{C} / \mathrm{min}$ to $40^{\circ} \mathrm{C}$, and then finally cooled at a rate of $10{ }^{\circ} \mathrm{C} / \mathrm{min}$ to 70 ${ }^{\circ} \mathrm{C}$, after which the maxi-straws were plunged immediately into liquid nitrogen $\left(196^{\circ} \mathrm{C}\right.$ ) and stored for approximately $1 \mathrm{wk}$. When required, the maxi-straws were thawed in air for $1 \mathrm{~min}$ at room temperature $\left(25^{\circ} \mathrm{C}\right.$ ) and then immersed in a water bath at $37{ }^{\circ} \mathrm{C}$ until the cryoprotectant solution had completely melted. The cryoprotectant was then removed, as described above for the exposed ovarian tissue. After these procedures, all ovarian fragments L.S. Wanderley et al. / 
Theriogenology 77 (2012) 260-267 261 were fixed for histological and ultrastructural analysis (Fig. 1). Each treatment was repeated five times.

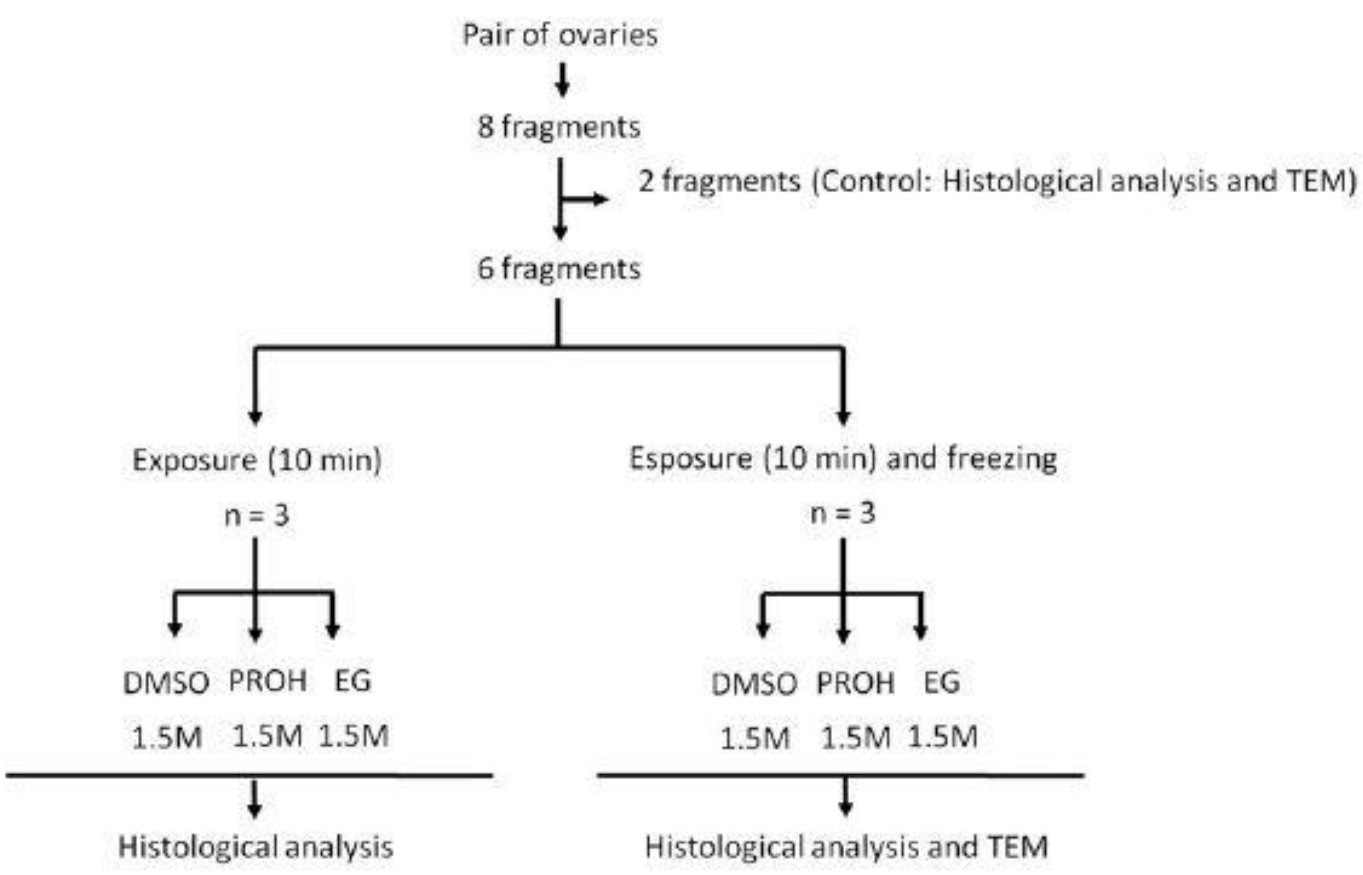

Fig. 1. Experimental design for exposure and freezing of agouti ovarian tissue. TEM, transmission electron microscopy.

\subsection{Histological analysis}

To assess morphology of cryopreserved agouti preantral follicles, fragments of ovarian tissue were processed according to Faustino et al [16], with some modifications. Briefly, samples were fixed in Carnoy for $4 \mathrm{~h}$, dehydrated in a graded series of ethanol, clarified with xylene, embedded in paraffin wax, and serially sectioned $(7 \mu \mathrm{m})$. Every fifth section was mounted on a glass slide, stained with hematoxylin and eosin (HE) and evaluated by light microscopy (Nikon, Tokyo, Japan) at $400 x$.

Preantral follicles were defined as an oocyte surrounded either by one layer of flattened or cuboidal granulosa cells, or several layers of cuboidal granulosa cells with no antrum. Only preantral follicles with visible nuclei were counted. Follicle morphology was evaluated based on the integrity of the oocyte, granulosa cells, and basement membrane. Preantral follicles were classified and counted as: (i) morphologically normal (MNPF) if they contained an oocyte with regular shape and uniform cytoplasm and organized layers of granulosa cells; or as (ii) 
degenerated if they exhibited disorganization of granulosa cells, a shrunken oocyte, oocyte cytoplasm vacuolization, or low granulosa cell density.

\subsection{Ultrastructural analysis}

To compare the ultrastructure of preantral follicles from the control, as well as from treatment groups with higher percentages of MNPF in the light microscopy evaluation, evaluation with transmission electron microscopy (TEM) was performed as described [17], with some modifications. Portions (maximum size, $1 \mathrm{~mm}$ ) were cut from each fragment of ovarian tissue and fixed in a modified Karnovsky solution (2\% paraformaldehyde and 2\% glutaraldehyde in a $0.1 \mathrm{M}$ sodium cacodylate buffer at a $\mathrm{pH}$ of 7.2 ) for $3 \mathrm{~h}$ at room temperature (RT, approximately $25^{\circ} \mathrm{C}$ ). After three washes in sodium cacodylate buffer, specimens were post-fixed in $1 \%$ osmium tetroxide, $0.8 \%$ potassium ferricyanide and $5 \mathrm{mM}$ calcium chloride in $0.1 \mathrm{M}$ sodium cacodylate buffer for $1 \mathrm{~h}$ at RT. Samples were then dehydrated through a gradient of acetone solutions and, thereafter, embedded in Spurr's epoxy resin. Afterwards, semithin sections $(5 \mathrm{~m})$ were cut, stained with toluidine blue, and analyzed by light microscopy at a 400x magnification. Ultra-thin sections $(60-80 \mathrm{~nm})$ were obtained from preantral follicles that were classified as morphologically normal in semi-thin sections, according to the criteria adopted for histology. Subsequently, ultra-thin sections were contrasted with uranyl acetate and lead citrate, and examined under a Jeol 1011 transmission electron microscope (Jeol, Tokyo, Japan) operating at 80 kV.

\subsection{Statistical analysis}

Analysis of variance was done using the GLM procedure of SAS (1999), according to a 32 factorial arrangement of treatments with the three cryoprotectants (DMSO, EG, and PROH) and two procedures (exposure only or exposure followed by cryopreservation) as the main effects. Differences among treatments were determined by a Student-Newman-Keuls procedure. The results were presented as the mean \pm SD and the differences were considered significant when $P<$ 0.05 . 

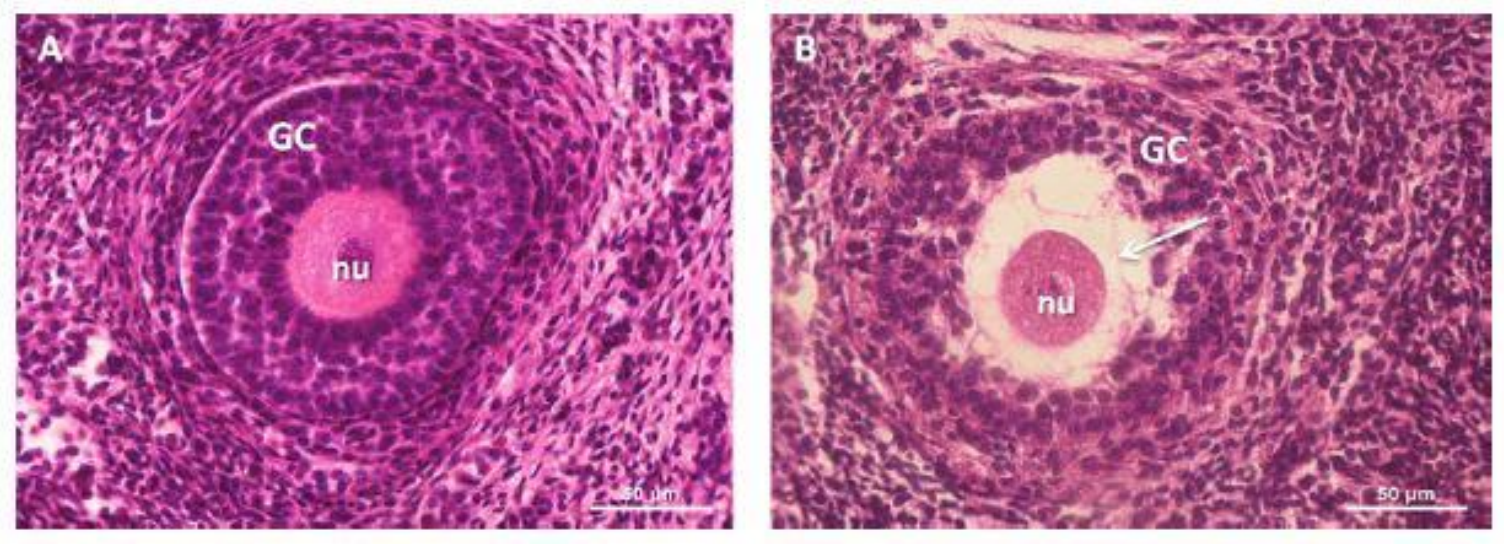

Fig. 2. Histological sections of agouti preantral follicles. (A) Morphologically normal follicle (control); (B) Degenerated follicle, cryopreserved with EG. Note retraction of the oocyte cytoplasm (arrow) and disorganized granulosa cells. Nu, oocyte nucleus; gc, granulosa cells.

\section{Results}

\subsection{Histological analysis}

A total of 1,050 preantral follicles were analyzed (150 follicles per treatment in five replicates). In general, normal (Fig. 2A) and degenerated (Fig. 2B) follicles were present in the control and all treatments. The percentages of MNPF found in the control and the treatments that were only exposed and/or cryopreserved in the presence of $1.5 \mathrm{M}$ of DMSO, EG, or PROH are shown (Fig. 3). In frozen-thawed tissues, there was a significant reduction in the percentage of morphologically normal follicles in all treatments compared to the control $(92.7 \% \pm 2.8)$. However, there were no significant differences when the procedures of exposure and freezing were compared to each other. Similarly, there were no significant differences among cryoprotectants after exposure only (DMSO: $64.7 \pm 3.8 \%$; EG: $70.7 \% \pm 11.2$, and PROH: $63.3 \% \pm$ 8.5 ) or after exposure followed by freezing (DMSO: $60.6 \% \pm 3.6$, EG: $64.0 \% \pm 11.0$; and PROH: $62.0 \% \pm 6.9$ ).

\subsection{Ultrastructural analysis}

Based on TEM, normal preantral follicles had an oocyte with homogeneous cytoplasm that was full of mitochondria with continuous membranes and peripheral cristae. Some elongated mitochondria with parallel cristae were also detected, whereas small Golgi complexes were rarely observed. Smooth and rough endoplasmic reticulum were present, alone or in association with the mitochondria. The oocyte nucleus was large and well delimited by the nuclear envelope and 
contained decondensed chromatin in some areas and aggregates of chromatin, and the nucleolus was frequently identified. Granulosa cells were small and had a high nucleus-cytoplasm ratio. Irregularly shaped nuclei of these cells contained decondensed chromatin on the inside and condensed chromatin in the periphery. The cytoplasm had numerous mitochondria and well developed smooth and rough endoplasmic reticulum. Membranes of the oocyte and the surrounding granulosa cells were closely juxtaposed. A distinct, continuous basement membrane surrounded the follicles and was strongly adhered to the stroma. A normal (Fig. 4A) and a degenerated (Fig. 2B) follicle are shown in Fig. 4. The normal pattern of ultrastructure was observed in the follicles of the control (Fig. 5A) and those cryopreserved with PROH (Fig. 5B), which proved to be the most effective cryoprotectant. However, changes were detected in the follicles that were cryopreserved with DMSO and EG and that had been considered normal in semithin sections when visualized with light microscopy. In follicles cryopreserved in the presence of DMSO, numerous vacuoles were seen in the ooplasm, in addition to a high degree of vacuolization in granulosa cells and the loss of the cytoplasmic content of these cells, leading to the formation of large void spaces in some cases (Fig. 5C). In follicles cryopreserved with EG, the ooplasm had reduced electron density and a small number of organelles that were heterogeneously distributed into small groups (Fig. 5D).

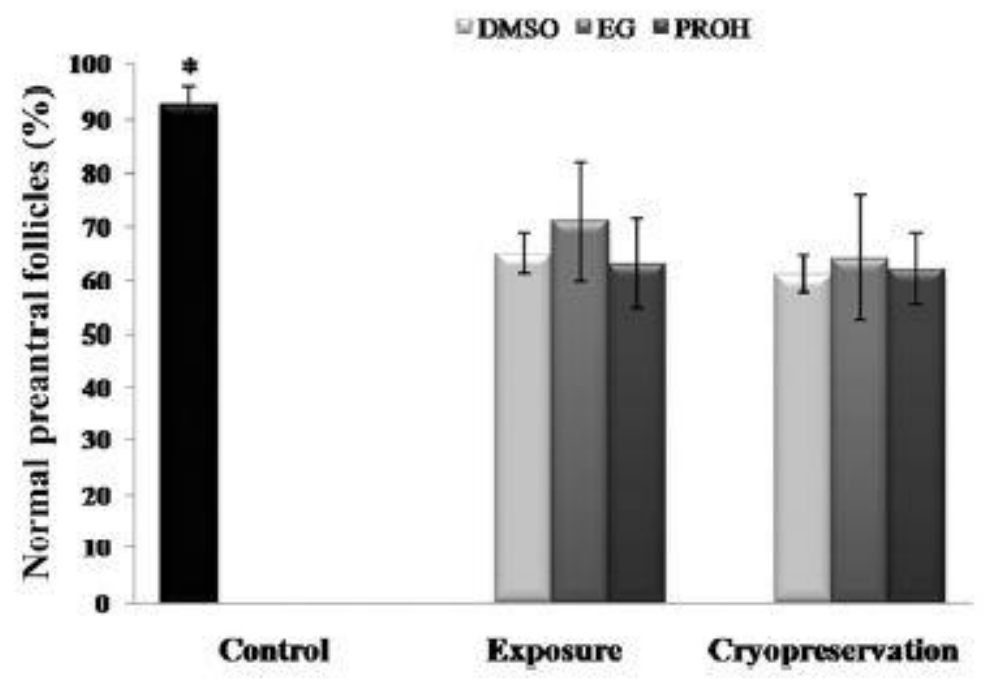

Fig. 3. Percentage of morphologically normal follicles in the control and after exposure to cryoprotectants (DMSO, EG or PROH) for $10 \mathrm{~min}$, with or without subsequent cryopreservation. *Differs from treatments $(\mathrm{P}<0.05)$. 

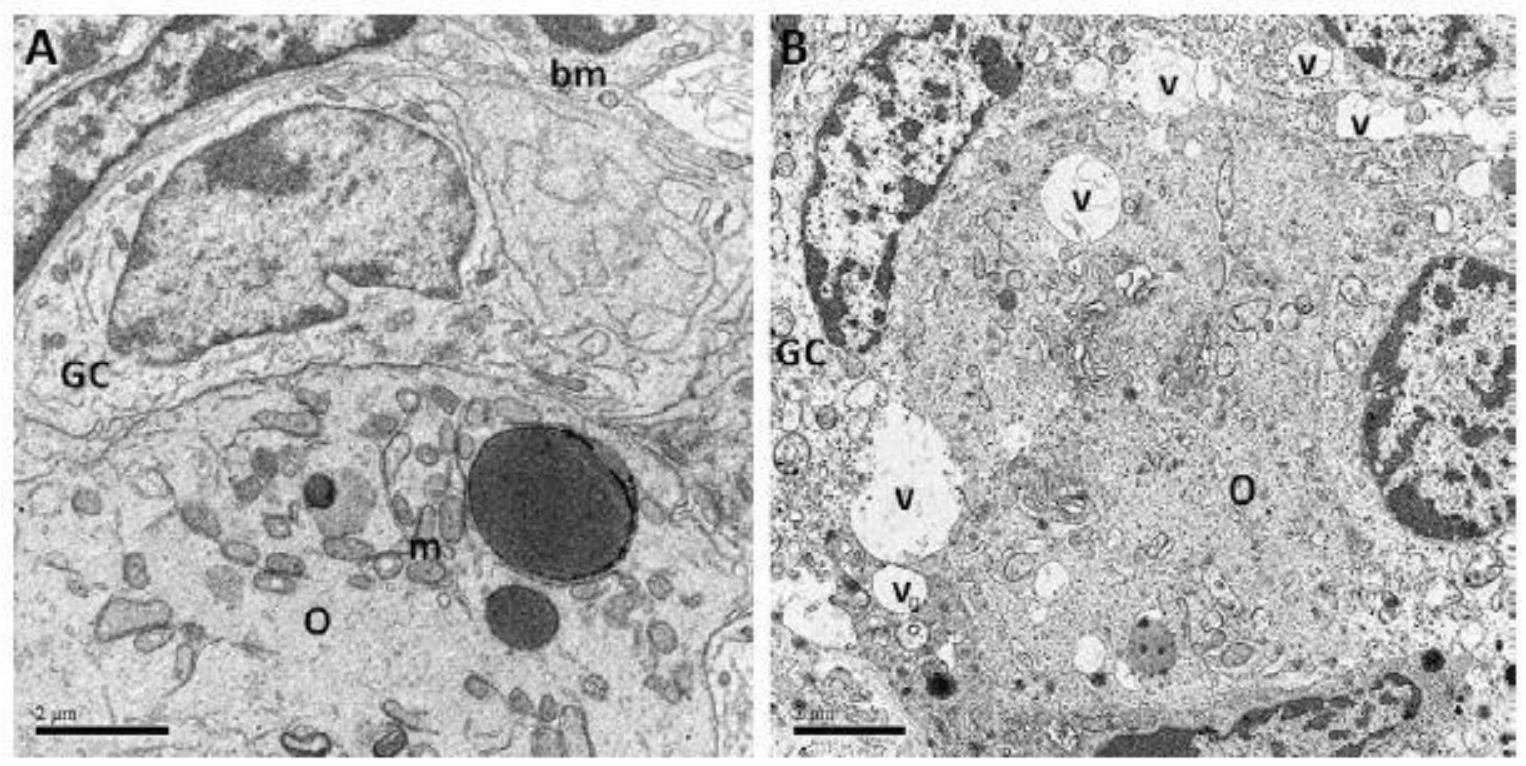

Fig. 4. Electron micrographs of a normal preantral agouti ovarian follicle from a control group (A, 12000x), and a frozen-thawed follicle with 1.5 M EG follicle (B, 10000x), displaying ultrastructural alterations. In Fig. $4 \mathrm{~B}$, note the intense ooplasm vacuolization. $\mathrm{O}$, oocyte; $\mathrm{GC}$, granulose cells; $\mathrm{m}$, mitochondria; bm, basement membrane; $v$, vacuole.

\section{Discussion}

The current study demonstrated, apparently for the first time, the cryopreservation of agouti (Dasyprocta aguti) ovarian tissue, using three cryoprotectants. In an attempt to choose the most suitable cryoprotectant agent to promote the cryoprotection of the agouti ovarian tissue and eliminate freezing-induced damage, PROH, DMSO, and EG were used, which have been widely used with success at concentrations of $1.5 \mathrm{M}$ [18]. In addition, this was apparently also the first study to report ultrastructural features of fresh and cryopreserved agouti preantral follicles.

Exposure of ovarian tissue fragments to $1.5 \mathrm{M}$ of the three tested cryoprotectants (DMSO, $E G$, or $\mathrm{PROH}$ ) significantly reduced percentages of preantral follicles with normal morphology compared to the control or fresh fragments. Similar changes were reported following exposure of ovarian tissue of sheep [19] and goats [2,3] to $1.5 \mathrm{M}$ concentrations of the same cryoprotectants. Despite protecting cells and tissues against cryoinjuries [20], the CPAs may cause damage by their toxic action [21], which can vary with concentration, time, and exposure temperature [22].

In the present study, the percentage of morphologically normal preantral follicles in the fragments that were only exposed to a CPA was similar to that observed after freezing and thawing. Therefore, we inferred that the reduction in the number of PAFs occurred mainly as a 
result of the exposure of the normal tissue to the cryopreservation solution, with agouti ovarian tissue being quite resistant to extreme reductions in temperature.

Follicle morphology, analyzed by classical histology, was not significantly different among the three cryoprotectants, tested in terms of the percentage of normal follicles after cryopreservation. However, with TEM, changes in the ultrastructure of cryopreserved follicles were apparent. Similar changes were reported after cryopreservation of porcine ovarian tissue with 1.5 M EG and DMSO [23]. It was noteoworthy that TEM was considered a good technique for analysis of cellular organelles and ultrastructural changes in cryopreserved ovarian tissue [24] and thus, was a better evaluation method than classical histology.

Follicle ultrastructure was better preserved in the presence of $\mathrm{PROH}$, which is considered a low-toxicity cryoprotectant that can protect cells against freezing-induced dehydration [25] and thus is one of the CPAs that is most often used for cryopreservation of human oocytes [26]. In previous studies, $1.5 \mathrm{M}$ of this cryoprotectant yielded satisfactory results for cryopreservation of preantral follicles enclosed in the ovarian tissue of rabbits [27] and sheep [28]. In a recent study by our team, ovarian tissue of goats was successfully cryopreserved in the presence of $1.0 \mathrm{M} \mathrm{PROH}$ (unpublished data). In contrast, Oskam et al [29], reported that PROH caused deleterious effects to the stroma and cryopreserved PAFs of ovine ovarian tissue.

In the present study, ovarian tissue cryopreserved with DMSO had a greater degree of vacuolization in both the ooplasm and granulosa cells, which coalesced to form voids. Unlike results previously reported in our studies in pigs [23], cattle [30], and sheep [19], DMSO was able to maintain the ultrastructure of preantral follicles enclosed in ovarian tissue after cryopreservation. In follicles included in ovarian tissue that were cryopreserved in the presence of $E G$, greater damage was observed in this study, manifested as reduced electron density and fewer organelles in the ooplasm. These findings differed from those in goats [2] and cattle [31], in which the cryoprotectant agent was highly efficient in maintaining follicle ultrastructure.

We speculated that apparent differences between the results obtained in this study and those previously reported were due to differences between protocols and the efficiency of the cryoprotectants. In that regard, the latter was closely related to the organization of ovarian tissue and associated with species-specific characteristics [32], not allowing for extrapolation of protocols for species that are phylogenetically distant.

In conclusion, preantral follicles enclosed in agouti ovarian tissue were successfully cryopreserved using 1.5 M PROH; the rate of MNPF was satisfactory and ultrastructure was best 
preserved with this CPA. This protocol should be of great importance both for the preservation of the species itself and for other endangered wild rodents whose ovaries have similar characteristics.
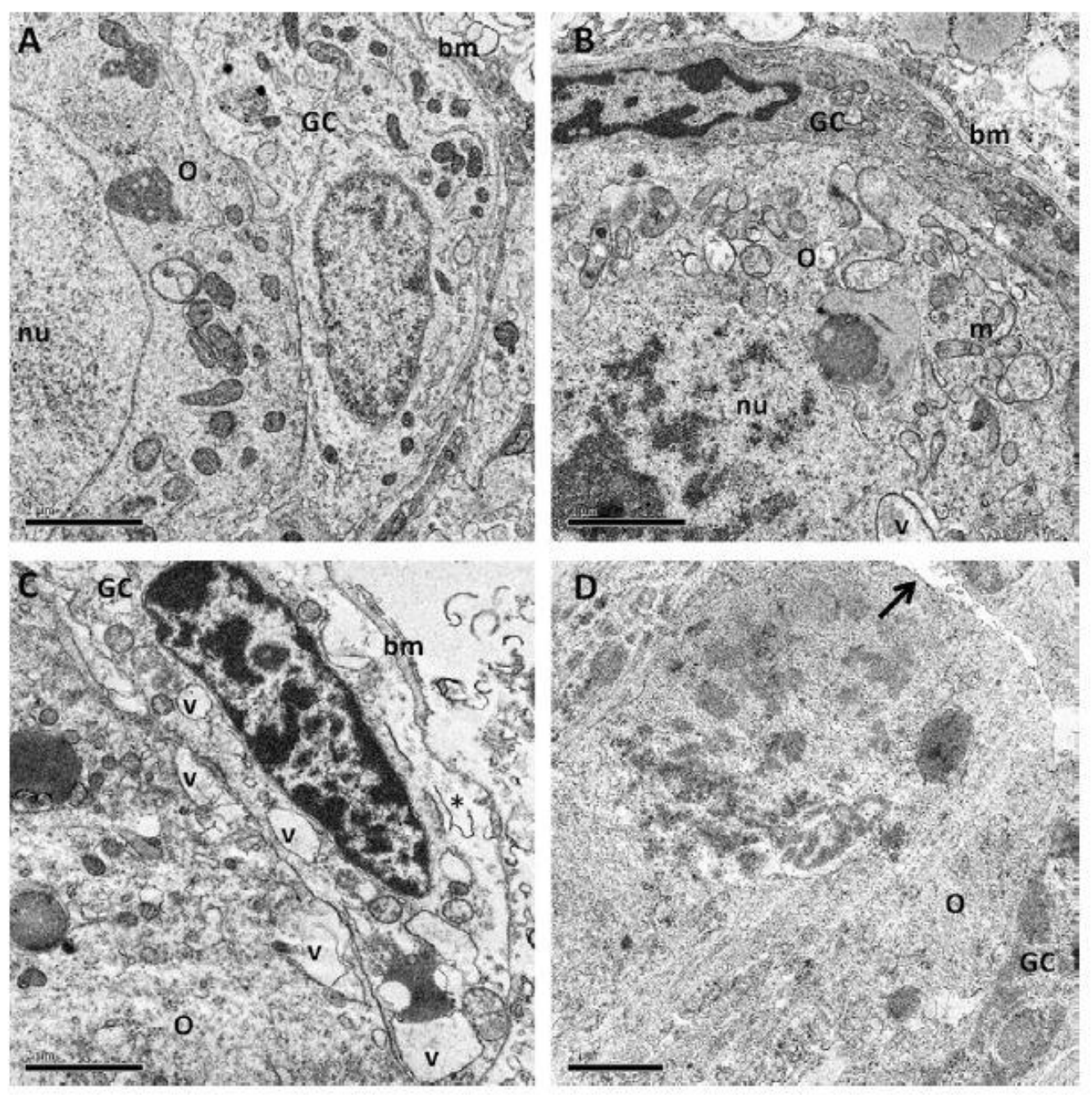

\section{Acknowledgments}

This work was supported by CNPq (RENORBIO: grant no. 554812/2006-1). L.S. Wanderley is a recipient of a grant from CNPq (Brazil). The authors thank the staff of the Centre of Multiplication of Wild Animals from Rural Federal University of Semi-Arid for providing the animals used in this experiment.

\section{References}

[1] Imhof M, Bergmeister H, Lipovac M, Rudas M, Hofstetter G, Huber J. Orthotopic microvascular reanastomosis of whole cryopreserved ovine ovaries resulting in pregnancy and live birth. Fertil Steril 2006;85:1208-15. 
[2] Rodrigues APR, Amorim CA, Costa SHF, Matos MHT, Santos RR, Lucci CM, Báo SN, Ohashi OM, Figueiredo JR. Cryopreservation of caprine ovarian tissue using glycerol and ethylene glycol. Theriogenology 2004;61:1009-24.

[3] Rodrigues APR, Amorim CA, Costa SHF, Matos MHT, Santos RR, Lucci CM, Báo SN, Ohashi OM, Figueiredo JR. Cryopreservation of caprine ovarian tissue using dimethylsulphoxide and propanediol. Anim Reprod Sci 2004;84:211-27.

[4] Candy CJ, Wood MJ, Whittingham DG. Follicular development in cryopreserved marmoset ovarian tissue after transplantation. Hum Reprod 1995;10:2334-8.

[5] Li S, Qin B-L, Li F, Shi Z-D, Tian Y-B, Chen X-J. Offspring from heterotropic transplantation of newborn mice ovaries. Reprod Domest Anim 2009;44:764 -70.

[6] Ernst E, Bergholdt S, Jørgensen JS, Andersen CY. The first woman to give birth to two children following transplantation of frozen/thawed ovarian tissue. Hum Reprod 2010;25:1280 -1.

[7] Pukazhenthi BS, Comizzoli P, Travis A, Wildt, DE. Applications of emerging technologies to the study and conservation of threatened and endangered species. Reprod Fertil Dev 2006;18: 77-90. [8] Hamelett WC, Rasweiler IV JJ. Comparative gestation and placentation in vertebrates. J Exp Zool 1993;266:343-6.

[9] Björkman N, Dantzer V, Leiser R. Comparative placentation in laboratory animals - a review. Scand J Lab Anim Sci 1989;16: 129-58.

[10] Rodrigues RF, Miglino MA, Ferraz RHS, Morais-Pinto, L de. Placentação em cutias (Dasyprocta aguti, CARLETON, M.D.): aspectos morfológicos. Braz J Vet Res Anim Sci 2003;40: 133-7.

[11] Conceição RA, Ambrósio CE, Martins DS, Carvalho AF, Franciolli ALR, Machado MRF, Oliveira MF, Miglino MA. Aspectos morfológicos do saco vitelino em roedores da subordem Hystricomorpha: paca (Agouti paca) e cutia (Dasyprocta aguti). Pesq Vet Bras 2008;28:253-9.

[12] Almeida MM, Carvalho MAM, Cavalcante Filho MF, Miglino MA, Menezes DJA. Estudo morfológico e morfométrico do ovário de cutias (Dasyprocta aguti, Linnaeus, 1766). Braz J Vet Res Anim Sci 2005;40:55- 62.

[13] Fortes EAM, Carvalho MAM, Almeida MM, Conde Júnior AM, Cruz NEA, Assis Neto AC. Aspectos morfológicos da tuba uterina de cutias (Dasyprocta aguti, Mammalia: Rodentia). Braz J Vet Res Anim Sci 2005;42:135- 42.

[14] Mollineau WM, Adogwa AO, Garcia GW. A preliminary technique for electro-ejaculation of agouti (Dasyprocta leporina). Anim Reprod Sci 2008;108:92-7.

[15] Mollineau WM, Adogwa AO, Garcia GW. Liquid and frozen storage of agouti (Dasyprocta leporina) semen extended with UHT milk, unpasteurized coconut water, and pasteurized coconut water. Vet Med Int 2010 Sep 14;2010. pii: 702635. 
[16] Faustino LR, Santos RR, Silva CMG, Pinto LC, Celestino JJH, Campello CC, Figueiredo JR, Rodrigues APR. Goat and sheep ovarian tissue cryopreservation: Effects on the morphology and development of primordial follicles and density of stromal cell. Anim Reprod Sci 2010;122:90 -7.

[17] Bruno JB, Celestino JJH, Lima-Verde IB, Lima LF, Matos MHT, Araújo VR, Saraiva MVA, Martins FS, Name KPO, Campello CC, Báo SN, Silva JRV, Figueiredo JR. Expression of vascular endothelial growth factor (VEGF) receptor in goat ovaries and improvement of in vitro caprine preantral follicle survival and growth with VEGF. Reprod Fertil Dev 2009;21:679-87.

[18] Amorim CA, Gonçalves PBD, Figueiredo JR. Cryopreservation of oocytes from pre-antral follicles. Hum Reprod Update 2003; 9:119-29.

[19] Santos RR, Rodrigues APR, Costa SHF, Silva JRV, Matos MHT, Lucci CM, Báo SN, Van Den Hurk $\mathrm{R}$, Figueiredo JR. Histological and ultrastructural analysis of cryopreserved sheep preantral follicles. Anim Reprod Sci 2006;91:249-63.

[20] Gunasena KT, Villines PM, Critser ES, Critser JK. Live births after autologous transplant of cryopreserved mouse ovaries. Hum Reprod 1997;12:101-6.

[21] Mullen SF, Li M, Li Y, Chen ZJ, Critser JK. Human oocyte vitrification: The permeability of metaphase II oocytes to water and ethylene glycol and the appliance toward vitrification. Fertil Steril 2008;89:1812-25.

[22] Rall WF. Factors affecting the survival of mouse embryos cryopreserved by vitrification. Cryobiology 1987;24:387-402.

[23] Borges EN, Silva RC, Futino DO, Rocha-Junior CM, Amorim CA, Báo SN, Lucci CM. Cryopreservation of swine ovarian tissue: effect of different cryoprotectants on the structural preservation of preantral follicle oocytes. Cryobiology 2009; 59:195-200.

[24] Salehnia M, Moghadam EA, Velojerdi MR. Ultrastructure of follicles after vitrification of mouse ovarian tissue. Fertil Steril 2002;78:644 -5.

[25] Wusteman M, Rauen U, Simmonds J, Hunds N, Pegg DE Reduction of cryoprotectant toxicity in cells in suspension by use of a sodium-free vehicle solution. Cryobiology 2008;56:72-9.

[26] Küçük T, Baser I. Cryopreservation of female fertility: A review on the basics of cryobiology for obstetrics and gynecology residents. Eur Clin Obstet Gynaecol 2007;3:97-102. 266 L.S. Wanderley et al. / Theriogenology 77 (2012) 260-267

[27] Neto V, Buff S, Lornage J, Bottollier B, Guerin P, Joly T. Effects of different freezing parameters on the morphology and viability of preantral follicles after cryopreservation of doe rabbit ovarian tissue. Fertil Steril 2008;89:1348 -56.

[28] Gutiérrez GA, Vargas AMA, Corona MA, Becerra E, González OC, Mendoza HS, Monroy AE, Tovar CG. Gestation in sheep after autotransplantation with cryopreserved ovarian tissue: 
evidence for oocyte viability after the freezing and transplantation procedures. Ginecol Obstet Mex 2003;71:5-11.

[29] Oskam IC, Asadi BA, Santos RR. Histologic and ultrastructural features of cryopreserved ovine ovarian tissue: deleterious effect of 1,2-propanediol applying different thawing procedures. Fertil Steril 2010;93:2764-6.

[30] Lucci CM, Kacinskis MA, Lopes LHR. Rumpf, R. Báo SN. Effect of different cryoprotectants on the structural preservation of follicles in frozen zebu bovine (Bos indicus) ovarian tissue, Theriogenology 2004;61:1101-14.

[31] Mazoochi T, Salehnia M, Valojerdi MR, Mowla J. Morphologic, ultrastructural, and biochemical identification of apoptosis in vitrified-warmed mouse ovarian tissue. Fertil Steril 2008; 90:1480-6.

[32] Celestino JJH, Santos, RR, Lopes CAP, Martins FS, Matos MHT, Melo MAP, Báo SN, Rodrigues $A P R$, Silva JRV, Figueiredo JR. Preservation of bovine preantral follicle viability and ultra-structure after cooling and freezing of ovarian tissue. Anim Reprod Sci 2008;108:309 -18. 